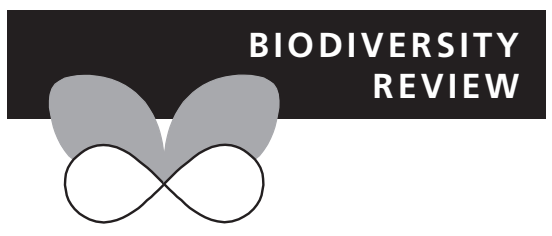

\title{
Diversity, distribution and conservation status of island conifers: a global review
}

\author{
Beatriz Rumeu ${ }^{1 \star}$, Virginia Afonso ${ }^{1}$, José María Fernández-Palacios ${ }^{2}$ and \\ Manuel Nogales ${ }^{1}$
}

${ }^{1}$ Island Ecology and Evolution Research Group (IPNA-CSIC), C/Astrofisico Fco. Sánchez, 3, 38206 La Laguna, Tenerife, Canary Islands, Spain, ${ }^{2}$ Island Ecology and Biogeography Research Group, Instituto Universitario de Enfermedades Tropicales y Salud Pública de Canarias, Universidad de La Laguna, La Laguna 38206, Tenerife, Canary Islands, Spain

${ }^{*}$ Correspondence: Beatriz Rumeu, Island Ecology and Evolution Research Group (IPNA-CSIC), C/Astrofísico Fco. Sánchez 3, 38206 La Laguna, Tenerife, Canary Islands, Spain.

E-mail: bea.rumeu@gmail.com

\section{ABSTRACT}

Aim Conifers comprise an ancient and diverse group of plants showing a wide distribution range. To better understand the general patterns of species successfully established on islands, this review compiles information about the distribution, diversity, dispersal potential and conservation status of insular conifers, with special emphasis on those inhabiting remote oceanic islands.

Location Global.

Methods An exhaustive survey was made of world-wide databases and literature. We registered information on island distribution (including ocean region, extension and geological origin of the island), endemism and threat status for each insular conifer.

Results 285 of the 547 conifer species considered in this review show an insular distribution (i.e. their distribution encompass insular territories). The family Podocarpaceae is best represented, with $40 \%$ of the insular species. The importance of endozoochory for long-distance dispersal is clear, because it was the most frequent dispersal syndrome among oceanic conifers. A high proportion of the total threatened conifers occur on islands (52\%), and many of them are insular endemics (72\%). Among conifer families, Araucariaceae is the most threatened in insular territories.

Main conclusions Our results highlight the wide diversity of insular conifers, as well as the key role of oceanic islands in catalysing speciation mechanisms. Pacific islands in particular harbour the greatest diversity levels, constituting a major centre of diversification. The wide distribution of conifers reflects their great potential for dispersal and colonization, endozoochory being the most favourable dispersal syndrome for reaching remote islands. The general threat status of insular conifers highlights the fragility of island biota and the urgent need for policies focused on their preservation.

\section{Keywords}

Biogeography, dispersal potential, dispersal syndromes, gymnosperms, insular environments, threat degree.

\section{INTRODUCTION}

Together with cycads, the ginkgo and the species from Gnetales, conifers are one of the four extant groups of gymnosperms that remain as a small example of what once covered the earth (Farjon, 2008). Conifers descended from a common ancestor in the late Palaeozoic, more than 300 million years ago (Chaw et al., 2000; Eckenwalder, 2009). According to Eckenwalder (2009), there are nearly 550 spp. grouped into 67 genera and six families (Araucariaceae, Cupressaceae,
Pinaceae, Podocarpaceae, Sciadopityaceae and Taxaceae). Conifers live on every continent except Antarctica, where they have been found only as fossils (e.g. Francis \& Poole, 2002). Asia has the greatest species richness of conifers, harbouring 39 of the 67 genera and about 200 of the total species (Eckenwalder, 2009).

Biological characteristics of conifers include a huge variation in size, from dwarf individuals growing only $10-25 \mathrm{~cm}$ such as Microcachrys tetragona (Podocarpaceae), to giant 90-m-high sequoias (Sequoiadendron giganteum) (Farjon, 
2008). Conifers are also characterized by their longevity (individuals of Pinus longaeva, Fitzroya cupressoides or S. gigante$u m$ have been estimated to be more than 3000 years old) and adaptation to harsh environments. They are distributed over a wide altitudinal range from sea level to elevations above $4,500 \mathrm{~m}$ a.s.l. (Abies, Larix and Juniperus) in areas near Mount Everest (Farjon, 2008; Eckenwalder, 2009). The reproductive organs are separated into male and female cones; however, conifers vary in their breeding system from species where individuals produce both types of cone (monoecy), to those with individuals bearing only one type (dioecy) (Leslie et al., 2013). Male cones (pollen cones) are simple, and pollen is dispersed by wind; and female cones (seed cones) are compound or reduced, with scales and bracts whose forms determine the dispersal syndrome (Farjon, 2008; Eckenwalder, 2009). Thus, all Araucariaceae and many Pinaceae have seeds with long wings, being typically wind-dispersed, whereas Taxaceae, nearly all Podocarpaceae and junipers (within Cupressaceae) have fleshy cones, cone parts or seeds. For these taxa, endozoochory is the main seed dispersal syndrome. Another type of animal dissemination is the scatter-hoarding seed dispersal mechanism, which involves species (mostly pines) with cones generally similar to those of wind-dispersed species, but showing scales that remain closed or gape just a little. These seeds are extracted and stored by squirrels and corvids, providing a chance of germination if they escape winter consumption (Vander Wall \& Balda, 1981; Johnson et al., 2003; Vander Wall, 2003). Finally, serotinous-cone species (mostly among pines and cypresses of the Northern Hemisphere) retain viable seeds within their unopened cones for years until a forest fire causes the cone to open (He et al., 2012).

The distribution of conifers encompasses a high number of oceanic islands. These islands arise from the oceanic floor as a result of underwater geological activity and have never been connected to continental land masses. As a general rule, their geological origin and isolation underlie the mechanisms of species formation and adaptive radiation (Losos \& Ricklefs, 2009), resulting in typically high levels of endemism (Emerson, 2002). Despite the extensive knowledge of conifer diversity and distribution across the world (e.g. Eckenwalder, 2009; Farjon, 2010), little is known about their levels of diversity and endemism in insular territories, and the distribution of this diversity across the oceans.

Colonization of oceanic islands involves different mechanisms of long-distance dispersal to cross relatively to very large spans of water (Gillespie et al., 2012; Nogales et al., 2012). The effectiveness of these methods is still a controversial issue, although dispersal by water or through bird assistance has been described as the most effective in traversing long distances (Renner, 2004; Gillespie et al., 2012). Angiosperms have successfully colonized the most remote islands of the world (Carlquist, 1967); however, despite the extensive range of conifers, there is a current lack of knowledge about their seed dispersal potential to overcome large spans of water.

Insularity is inevitably related to restricted habitats, and unfortunately, habitat destruction on oceanic islands has perhaps been the most important factor in causing the decline of island plants in the past (see Caujapé-Castells et al., 2010 and references therein). Thus, insularity and its associated vulnerability could in itself represent a threat to conifers inhabiting islands, especially to endemics with highly restricted distributions. Small islands support naturally small populations restricted to small geographical areas (MacArthur \& Wilson, 1967; Caujapé-Castells et al., 2010). Such populations are more prone to extinction than continental ones because of the high likelihood that habitat change will negatively influence population size (Gaston, 2009). When a species becomes rare, it is especially vulnerable to extinction due to environmental and demographic stochasticity, and lower genetic variability (Pimm et al., 1988; Frankham, 1998). Therefore, a lesser degree of threat is to be expected in those conifers showing a continental distribution. About a third of all conifer species are threatened throughout their geographical ranges (Farjon, 2008; Eckenwalder, 2009). Nevertheless, the balance between threatened insular and noninsular conifers has not yet been evaluated, nor the possible relationship between the degree of threat and conifer distribution in oceanic islands.

In the following overview, we gather information to determine (1) the diversity of island conifers (i.e. conifers whose distribution range include islands) and their degree of endemism, (2) the general pattern of distribution and richness of island conifers across oceans, (3) which dispersal syndromes lead to colonization of remote islands by conifers and (4) the conservation status of conifers from insular territories.

General perspectives are essential to understand species distributions and their conservation. Therefore, a global approach to conifer diversity and distribution on islands, and to their current conservation status, is an important requirement for progress in the development of general models and forest conservation strategies for islands.

\section{METHODS}

We compiled data on conifer distribution and conservation status mainly from the Gymnosperm database (http://www. conifers.org/) and the IUCN Red List of Threatened Species version 2013.1 (http://www.iucnredlist.org/). Only in four specific taxa not listed in the IUCN Red List (Agathis australis, Agathis endertii, Dacrydium ericoides and Pinus lagunae), we assigned the conservation status found in the Gymnosperm database, which follows Farjon \& Page (1999). In addition, as we previously had compiled the conservation status from the IUCN Red List of Threatened Species Version 2011.2, we could assess changes in the threat categories. The taxonomy follows Eckenwalder (2009), and taxa were considered only to the species level (ignoring lower levels such as subspecies or varieties).

In this review, islands have been classified into four categories according to their origin: (1) continental islands, that is, islands located on the continental shelf that were probably connected to the mainland during the Quaternary ice ages, 
when periods of significantly lower sea levels occurred, (2) continental fragments, that is, islands that have formed after breaking away from a continent by plate tectonic processes, (3) volcanic or oceanic islands, that is, those that have emerged de novo as a consequence of the volcanic activity from the seafloor, having never been connected to continental land masses; and (4) mixed, that is, islands with a complex origin which involves the combination of a continental origin and intense volcanic activity giving rise to part of the emerged surface (Whittaker \& Fernández-Palacios, 2007). Heterogeneous archipelagos such as the Philippines or Japan, where islands of different origin are grouped together, were also designated as mixed in origin.

For each species showing an insular distribution, we noted its oceanic region of occurrence (for which five regions were considered: North Pacific, South Pacific, Indian Ocean, North Atlantic and South Atlantic), its conservation status, the type of island according to its origin and the area of the island or archipelago where it occurs. For those conifers naturally distributed on islands of volcanic or mixed origin, we also obtained the distance to the nearest mainland from Google Earth.

Comparisons between the datasets were performed using categorical analyses ( $G$-test) implemented in IBM sPSS STATISTICS v20 (IBM Corporation, New York, NY, USA). In those cases where the use of the same dataset was required, we applied the Bonferroni correction to assess statistical significance avoiding type-I error. Spearman's correlations between the area of the islands and its diversity (measured as conifer species richness), and between distance to mainland and endozoochory syndrome, were analysed after confirming the nonparametric nature of the data by the Shapiro-Wilk normality test. Both analyses were performed using R v3.0.0 (R Core Team, 2013).

Despite our best efforts, we are aware that much precise information may have escaped our search, especially that related to conifer distribution on continental islands very close to continental land masses or island-rich groups. However, we are confident that this novel overview gathers together the scattered information available up-to-date and captures the general patterns of diversity, distribution and conservation status displayed by insular conifers, with special emphasis on those that have colonized remote oceanic islands.

\section{RESULTS}

\section{Diversity of island conifers}

All six conifer families and around a half (52\%) of the 547 species occur on islands (Table 1, Appendix S1). The family Podocarpaceae is the most widely represented in insular ecosystems, comprising $40 \%$ of the 285 insular conifer species, followed by Cupressaceae (25\%), Pinaceae (21\%), Araucariaceae $(10 \%)$, Taxaceae $(4 \%)$ and Sciadopityaceae $(0.4 \%)$. However, in relation to the number of species comprised in each family and taking aside the Sciadopityaceae with only one species, $83 \%$ of the conifer species from Araucariaceae occur on islands, followed by Podocarpaceae (73\%), Taxaceae $(65 \%)$, Cupressaceae $(46 \%)$ and Pinaceae (32\%) (Table 1). Of all insular species, 87 have colonized islands of oceanic and mixed origin, and 37 of these 87 species (43\%) occur on islands of exclusively oceanic origin (Appendix S1). As was expected, islands of continental origin (continental islands and continental fragments) harbour a significantly higher number of conifer species $(44 \%$ of the total conifer taxa) than islands of oceanic and mixed origin (16\%) (G-test: $\left.G_{1}=106.40, P<0.001\right)$. However, this significant difference disappears if we focus on the diversity of endemic species, which are evenly distributed over these islands with different origins $(47 \%$ and $39 \%$ in continental vs. oceanic and mixed-origin islands, respectively) (G-test: $G_{1}=1.59$, $P=0.208)$.

The rule of species-area relationship is fulfilled in the case of insular conifers. Thus, larger islands harbour a significantly greater number of conifer species than do islands with smaller area $\left(r_{s}=0.63, P<0.001\right)$ (Fig. 1a). Considering only endemic species, bigger islands also harbour a greater number of species than do smaller islands $\left(r_{s}=0.29\right.$, $P<0.005$ ) (Fig. 1b).

\section{Geographical distribution}

Conifers have colonized island territories distributed across all the oceans (North and South Pacific, North and South Atlantic and Indian Ocean) except for the Arctic and Antarctic oceans, ranging in latitude from Iceland $\left(65^{\circ} \mathrm{N}\right)$ to Tierra del Fuego ( $55^{\circ} \mathrm{S}$ ) (Fig. 2). Following the general pattern of geographical distribution displayed by continental conifer species, the ocean region harbouring the greatest diversity is the South Pacific, which comprises $51 \%$ of the insular species (Tables 1 and 2). This figure is significantly higher than for the other ocean regions ( $G$-test, $P<0.001$ for all comparisons after Bonferroni correction). It is notable that $86 \%$ of all insular species from the family Podocarpaceae occurs in the South Pacific region (Table 1). In this southern ocean, the conifer diversity found on islands such as New Caledonia (44 spp.), New Guinea (36 spp.) or New Zealand (20 spp.) is outstanding. Although New Caledonia is not one of the larger islands, it is the most diverse one. In both New Zealand and New Caledonia, $\geq 95 \%$ of the conifer species are endemic (see Table 2 and Fig. 2). Islands located in the North Pacific, among which the Japanese archipelago stands out, also harbour a noteworthy proportion of insular conifers (34\%), followed by those in the North Atlantic (18\%), in the Indian Ocean $(6 \%)$ and in the South Atlantic $(0.7 \%)$. The number of conifer species distributed in the North Pacific includes $60 \%$ of all pine species occurring on islands (Table 1), and overall, it is a figure significantly greater than that of the North Atlantic, the Indian and the South Atlantic Oceans. The diversity of the North Atlantic, in turn, is significantly higher than that observed in the Indian and the South Atlantic Ocean. With only two conifer taxa, the South 
Table 1 Summary of the number of conifer species distributed all over the world and on islands of five oceanic regions, and representation of families. The 'Total' column shows numbers of all conifer species world-wide, whereas the following columns show figures of conifers with an insular distribution

\begin{tabular}{|c|c|c|c|c|c|c|c|}
\hline & Total & Total on islands & North Pacific & South Pacific & Indian Ocean & North Atlantic & South Atlantic \\
\hline No. of conifer species & 547 & $285(52) *$ & $98(34)$ & $146(51)$ & $17(6)$ & $50(18)$ & $2(0.7)$ \\
\hline \multicolumn{8}{|c|}{ Representation of families } \\
\hline Araucariaceae & 35 & $29(83)^{*}$ & $1(3)$ & $29(100)$ & $0(0)$ & $0(0)$ & $0(0)$ \\
\hline Cupressaceae & 151 & $70(46)^{*}$ & $31(44)$ & $16(23)$ & $6(9)$ & $19(27)$ & $1(1)$ \\
\hline Pinaceae & 187 & $60(32)^{*}$ & $36(60)$ & $1(2)$ & $0(0)$ & $24(40)$ & $0(0)$ \\
\hline Podocarpaceae & 156 & $114(73) *$ & $21(18)$ & $98(86)$ & $11(10)$ & $5(4)$ & $1(1)$ \\
\hline Sciadopityaceae & 1 & $1(100)^{*}$ & $1(100)$ & $0(0)$ & $0(0)$ & $0(0)$ & $0(0)$ \\
\hline Taxaceae & 17 & $11(65) *$ & $8(73)$ & $2(18)$ & $0(0)$ & $2(18)$ & $0(0)$ \\
\hline
\end{tabular}

Numbers in brackets are percentages.

*Percentages respect to the 'Total' column; the remaining percentages are calculated regarding to the 'Total on islands' column.

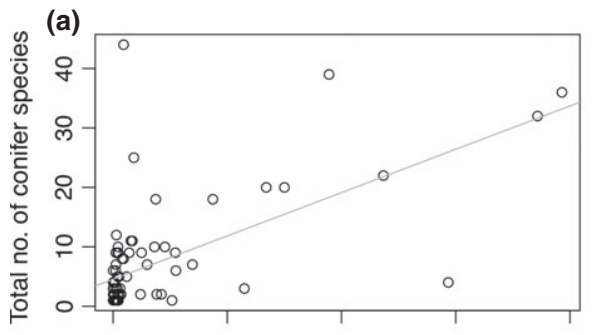

(b)

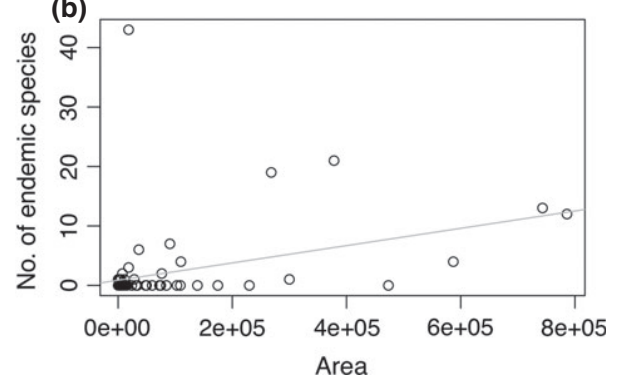

Figure 1 Scatterplots with the regression lines showing diversity of conifers ( $y$-axis) vs. island area ( $x$-axis). Top: total insular conifer species vs. island area. Bottom: endemic insular species vs. island area. Spearman's correlation showed a significant positive trend in both cases (No. of conifers vs. area: $r_{s}=0.63, P<0.001 ;$ No. of endemics vs. area: $r_{s}=0.29$, $P<0.005)$.

Atlantic Ocean has significantly less diversity than the rest of the ocean regions ( $G$-test, $P<0.001$ for all comparisons after Bonferroni correction).

Regarding the diversity of endemic species, it is remarkable that $69 \%$ of the species distributed in the South Pacific are endemics to their islands of occurrence (Table 2). This percentage of endemic species was significantly greater than those of the rest of the ocean regions considered (North Pacific: 29\%, North Atlantic: 30\%, Indian Ocean: 24\%; $G$-test, $P<0.001$ for all comparisons after Bonferroni correction). The two species recorded in the South Atlantic (Lepidothamnus fonkii and Libocedrus uvifera) grow on Isla Grande de Tierra del Fuego, and they are not even exclusive to this huge continental island (Table 2).

\section{Seed dispersal potential}

Examining the dispersal syndromes of conifers, $65 \%$ of the species that have an oceanic insular distribution exhibit endozoochory, which is significantly greater ( $G$-test: $G_{1}=8.65$, $P=0.003)$ than in those species distributed on continental land masses and islands of other origins, of which endozoochory is exhibited in $40 \%$ of the cases. This significant difference is also noted when contrasting endozoochorous species from islands of both oceanic and mixed origin (56\%), and the rest of the conifers (with a continental or insular distribution) that have not colonized these types of islands (39\%) ( $G$-test: $\left.G_{1}=8.99, P=0.003\right)$. Among the non-endemic species from oceanic islands $(n=29)$, that is, species that have actually experienced long-distance colonization events and are not the results of radiation processes on the islands, $66 \%$ also show the endozoochorous syndrome. Figure 3 shows a significant positive trend in the percentage of conifers displaying endozoochory on oceanic and mixed islands as the distance from the nearest continent increases $\left(r_{s}=0.42, P<0.05\right)$.

\section{Conservation status}

Following the IUCN criteria (IUCN, 2013), threatened categories are three ranking from highest to lowest extinction risk: critically endangered (CR), that is, the best available evidence indicates that the taxon is facing an extremely high risk of extinction in the wild; endangered (EN), that is, the taxon is considered to be facing a very high risk of extinction in the wild; and vulnerable (VU), that is, the taxon is considered to be at high risk of extinction in the wild. According to our search, $31 \%$ of the 547 conifer species are threatened (CR, EN, VU) and $18 \%$ are highly endangered (CR, EN). These figures imply an increase in the threat level of $4 \%$ and $5 \%$, respectively, compared with the previous assessment (IUCN, Version 2011.2). A total of 41 species have acquired one of the three categories of threat (CR, EN or VU) after the last assessment, and 26 species already threatened have 
B. Rumeu et al.

Table 2 Geographical region, area $\left(\mathrm{km}^{2}\right)$, geological origin (G.O.), distance from mainland or nearest continental source (in brackets) $(\mathrm{km})$ of volcanic and mixed-origin islands, and summary on diversity and conservation status of native conifers from islands across the world

\begin{tabular}{|c|c|c|c|c|c|c|c|}
\hline Region - Island & Area $\left(\mathrm{km}^{2}\right)$ & G.O. & $\begin{array}{l}\text { Distance from } \\
\text { mainland }(\mathrm{km})\end{array}$ & No. taxa & No. end. & $\mathrm{VU}+\mathrm{EN}+\mathrm{CR}$ & $\mathrm{EN}+\mathrm{CR}$ \\
\hline \multicolumn{8}{|l|}{ North Pacific } \\
\hline Bonin Islands (Japan) & 79.4 & $\mathrm{O}$ & $\begin{array}{l}1990 \text { (910 to Honshu, } \\
\text { Japan) }\end{array}$ & 2 & 0 & 0 & 0 \\
\hline Cedros Island (Mexico) & 348.3 & M & 22.5 & 2 & 0 & 1 & 1 \\
\hline Guadalupe Island (Mexico) & 243 & $\mathrm{O}$ & 256 & 3 & 0 & 2 & 2 \\
\hline $\begin{array}{l}\text { Haida Gwaii (British Columbia, } \\
\text { Canada) }\end{array}$ & 10,180 & $\mathrm{C}$ & - & 5 & 0 & 0 & 0 \\
\hline Hainan (China) & 33,920 & $\mathrm{C}$ & - & 11 & 0 & 2 & 1 \\
\hline Japan & 377,944 & $\mathrm{M}$ & 170 & 39 & 21 & 4 & 3 \\
\hline Jeju (South Korea) & 1848 & $\mathrm{O}$ & 84 & 1 & 0 & 1 & 1 \\
\hline Kodiak (Alaska, USA) & 9311.2 & $\mathrm{C}$ & - & 1 & 0 & 0 & 0 \\
\hline Kuril Islands (Russia) & 15,600 & $\mathrm{O}$ & $\begin{array}{l}650 \text { (16.5 to Hokkaido, } \\
\text { Japan) }\end{array}$ & 8 & 0 & 0 & 0 \\
\hline Philippines & 300,000 & M & 660 (370 to Taiwan) & 20 & 1 & 8 & 5 \\
\hline Riau Islands (Indonesia) & 8201.7 & $\mathrm{C}$ & - & 1 & 0 & 0 & 0 \\
\hline Sakhalin (Russia) & 72,492 & $\mathrm{C}$ & - & 10 & 0 & 0 & 0 \\
\hline San Juan Islands (Washington, USA) & 496 & $\mathrm{C}$ & - & 2 & 0 & 0 & 0 \\
\hline Taiwan & 36,193 & FC & - & 25 & 6 & 10 & 6 \\
\hline Ullung Island (South Korea) & 73.2 & $\mathrm{O}$ & 132 & 1 & 0 & 0 & 0 \\
\hline $\begin{array}{l}\text { Vancouver (British Columbia, } \\
\text { Canada) }\end{array}$ & 31,285 & $\mathrm{C}$ & - & 12 & 0 & 0 & 0 \\
\hline \multicolumn{8}{|l|}{ South Pacific } \\
\hline $\begin{array}{l}\text { Bismarck archipelago } \\
\text { (Papua New Guinea) }\end{array}$ & 49,700 & $\mathrm{O}$ & $\begin{array}{r}875 \text { (92 km to } \\
\text { New Guinea) }\end{array}$ & 9 & 0 & 0 & 0 \\
\hline Borneo (Greater Sunda Islands) & 743,330 & $\mathrm{C}$ & - & 32 & 13 & 13 & 8 \\
\hline Chiloé (Chile) & 8394 & $\mathrm{C}$ & - & 2 & 0 & 2 & 1 \\
\hline Fiji & 18,274 & M & $\begin{array}{l}2600 \text { (1170 to } \\
\text { New Caledonia) }\end{array}$ & 8 & 3 & 3 & 3 \\
\hline Java (Greater Sunda Islands) & 138,794 & $\mathrm{C}$ & - & 7 & 0 & 1 & 0 \\
\hline $\begin{array}{l}\text { Maluku islands (syn. Moluccas, } \\
\text { Indonesia) }\end{array}$ & 74,505 & $\mathrm{C}$ & - & 18 & 0 & 2 & 0 \\
\hline $\begin{array}{l}\text { New Caledonia (sui generis } \\
\text { collectivity of France) }\end{array}$ & 18,576 & $\mathrm{FC}$ & - & 44 & 43 & 24 & 16 \\
\hline $\begin{array}{l}\text { New Guinea (Indonesia/Papua } \\
\text { New Guinea) }\end{array}$ & 786,000 & $\mathrm{C}$ & - & 36 & 12 & 3 & 0 \\
\hline New Zealand & 268,021 & $\mathrm{FC}$ & - & 20 & 19 & 0 & 0 \\
\hline Norfolk Island (Australia) & 34.6 & $\mathrm{O}$ & $\begin{array}{l}1400 \text { (745 to } \\
\text { New Caledonia) }\end{array}$ & 1 & 1 & 1 & 0 \\
\hline Solomon Islands & 28,400 & M & $\begin{array}{l}1670 \text { (650 to } \\
\text { New Guinea) }\end{array}$ & 9 & 1 & 1 & 1 \\
\hline $\begin{array}{l}\text { Sulawesi (syn. Celebes, Greater } \\
\text { Sunda Islands) }\end{array}$ & 174,600 & $\mathrm{C}$ & - & 18 & 0 & 3 & 2 \\
\hline Sumatra (Greater Sunda Islands) & 473,481 & $\mathrm{C}$ & - & 22 & 0 & 9 & 4 \\
\hline Tasmania & 90,758 & $\mathrm{C}$ & - & 10 & 7 & 3 & 0 \\
\hline Tonga archipelago & 748 & $\mathrm{O}$ & $\begin{array}{l}3240 \text { (1825 to } \\
\text { New Caledonia) }\end{array}$ & 1 & 1 & 1 & 0 \\
\hline Vanuatu & 12,190 & $\mathrm{O}$ & $\begin{array}{l}1810 \text { (570 to } \\
\text { New Caledonia) }\end{array}$ & 3 & 0 & 1 & 1 \\
\hline \multicolumn{8}{|l|}{ Indian Ocean } \\
\hline Dirk Hartog Island (Australia) & 620 & $\mathrm{C}$ & - & 1 & 0 & 0 & 0 \\
\hline Kangaroo Island (Australia) & 4405 & $\mathrm{C}$ & - & 3 & 0 & 0 & 0 \\
\hline Lesser Sunda Islands & 59,798 & M & 478 (2.3 to Java) & 7 & 0 & 0 & 0 \\
\hline Madagascar & 587,041 & FC & - & 4 & 4 & 3 & 3 \\
\hline
\end{tabular}


Table 2 Continued.

\begin{tabular}{|c|c|c|c|c|c|c|c|}
\hline Region - Island & Area $\left(\mathrm{km}^{2}\right)$ & G.O. & $\begin{array}{l}\text { Distance from } \\
\text { mainland }(\mathrm{km})\end{array}$ & No. taxa & No. end. & $\mathrm{VU}+\mathrm{EN}+\mathrm{CR}$ & $\mathrm{EN}+\mathrm{CR}$ \\
\hline Tiwi Islands (Australia) & 8320 & $\mathrm{C}$ & - & 1 & 0 & 0 & 0 \\
\hline Rottnest Island (Australia) & 19 & $\mathrm{C}$ & - & 1 & 0 & 0 & 0 \\
\hline \multicolumn{8}{|l|}{ North Atlantic } \\
\hline Anticosti Island (Canada) & 7923.2 & $\mathrm{C}$ & - & 5 & 0 & 0 & 0 \\
\hline Azores (Portugal) & 2333 & $\mathrm{O}$ & 1380 & 2 & 1 & 1 & 0 \\
\hline Bahamas & 13,878 & $\mathrm{C}$ & - & 2 & 0 & 1 & 0 \\
\hline Bermuda (British overseas territory) & 53.2 & $\mathrm{O}$ & 1100 & 1 & 1 & 1 & 1 \\
\hline Canary Islands (Spain) & 7493 & $\mathrm{O}$ & 100 & 3 & 2 & 1 & 1 \\
\hline Cape Breton Island (and surroundings) & 10,311 & $\mathrm{C}$ & - & 5 & 0 & 0 & 0 \\
\hline Faroes (Denmark) & 1399 & $\mathrm{O}$ & 620 (325 to Great Britain) & 1 & 0 & 0 & 0 \\
\hline Great Britain (UK) & 229,848 & $\mathrm{C}$ & - & 3 & 0 & 0 & 0 \\
\hline Iceland & 103,001 & $\mathrm{O}$ & 295 & 1 & 0 & 0 & 0 \\
\hline Ireland & 84,421 & $\mathrm{C}$ & - & 2 & 0 & 0 & 0 \\
\hline Isle of Man (UK) & 572 & $\mathrm{C}$ & - & 1 & 0 & 0 & 0 \\
\hline Long Island, New York (USA) & 3629 & $\mathrm{C}$ & - & 1 & 0 & 0 & 0 \\
\hline Madeira (Portugal) & 801 & $\mathrm{O}$ & 660 & 3 & 1 & 0 & 0 \\
\hline $\begin{array}{l}\text { Magdalen (Madeleine) Islands and } \\
\text { surroundings } \\
\text { (Gulf of Saint Lawrence) (Canada) }\end{array}$ & 205.5 & $\mathrm{C}$ & - & 4 & 0 & 0 & 0 \\
\hline Newfoundland (Canada) & 108,860 & $\mathrm{C}$ & - & 9 & 0 & 0 & 0 \\
\hline Prince Edward Island (Canada) & 5660 & $\mathrm{C}$ & - & 12 & 0 & 0 & 0 \\
\hline São Tomé (São Tomé and Príncipe) & 854 & $\mathrm{O}$ & 245 & 1 & 1 & 1 & 0 \\
\hline $\begin{array}{l}\text { Turks and Caicos Islands } \\
\text { (British overseas territory) }\end{array}$ & 616.3 & $\mathrm{C}$ & - & 1 & 0 & 0 & 0 \\
\hline \multicolumn{8}{|l|}{ Mediterranean Islands } \\
\hline Balearic Islands (Spain) & 4992 & $\mathrm{FC}$ & - & 7 & 0 & 0 & 0 \\
\hline Corsica (France) & 8680 & $\mathrm{FC}$ & - & 10 & 0 & 0 & 0 \\
\hline Crete (Greece) & 8336 & $\mathrm{FC}$ & - & 8 & 0 & 0 & 0 \\
\hline Cyprus & 9251 & FC & - & 9 & 0 & 1 & 0 \\
\hline East Aegean Islands (Greece) & 4562.7 & $\mathrm{C}$ & - & 6 & 0 & 0 & 0 \\
\hline Ionian Islands (Greece) & 2585.3 & $\mathrm{C}$ & - & 1 & 0 & 0 & 0 \\
\hline Malta & 316 & $\mathrm{C}$ & - & 6 & 0 & 0 & 0 \\
\hline Sardinia (Italy) & 24,090 & FC & - & 5 & 0 & 0 & 0 \\
\hline Sicily (Italy) & 5043.5 & $\mathrm{FC}$ & - & 9 & 1 & 1 & 1 \\
\hline \multicolumn{8}{|l|}{ Baltic Islands } \\
\hline Aland Islands (Finland) & 1580 & $\mathrm{C}$ & - & 4 & 0 & 0 & 0 \\
\hline Gotland (Sweden) & 3183.7 & $\mathrm{C}$ & - & 4 & 0 & 0 & 0 \\
\hline Hiiumaa (Estonia) & 989 & $\mathrm{C}$ & - & 4 & 0 & 0 & 0 \\
\hline Öland (Sweden) & 1342 & $\mathrm{C}$ & - & 4 & 0 & 0 & 0 \\
\hline Saaremma (Estonia) & 2673 & $\mathrm{C}$ & - & 4 & 0 & 0 & 0 \\
\hline \multicolumn{8}{|l|}{ Caribbean Islands } \\
\hline Cuba (Greater Antilles) & 109,884 & $\mathrm{FC}$ & - & 6 & 4 & 4 & 1 \\
\hline Hispaniola (Greater Antilles) & 76,480 & FC & - & 3 & 2 & 2 & 2 \\
\hline Jamaica (Greater Antilles) & 10,991 & FC & - & 2 & 1 & 2 & 1 \\
\hline Leewards (Lesser Antilles) & 6453.4 & $\mathrm{O}$ & $\begin{array}{l}585 \text { (12.5 to } \\
\text { Puerto Rico) }\end{array}$ & 1 & 0 & 0 & 0 \\
\hline Martinique (Lesser Antilles) & 1128 & $\mathrm{O}$ & 425 & 1 & 0 & 0 & 0 \\
\hline Puerto Rico (Greater Antilles) & 9104 & $\mathrm{FC}$ & - & 1 & 0 & 0 & 0 \\
\hline Saint Lucia (Lesser Antilles) & 617 & $\mathrm{O}$ & 345 & 1 & 0 & 1 & 0 \\
\hline Trinidad (Trinidad and Tobago) & 4748 & $\mathrm{C}$ & - & 1 & 1 & 0 & 0 \\
\hline \multicolumn{8}{|l|}{ South Atlantic } \\
\hline Isla Grande de Tierra del Fuego & 47,992 & $\mathrm{C}$ & - & 2 & 0 & 1 & 0 \\
\hline
\end{tabular}

Geological origin: C, continental island; FC, continental fragment; M, mixed origin; O, oceanic island. No. taxa, total number of native conifers; No. end., number of endemic conifers; $\mathrm{VU}+\mathrm{EN}+\mathrm{CR}$, number of threatened taxa (vulnerable, endangered or critically endangered) according to the IUCN (2013); EN+CR, number of highly endangered taxa (endangered and critically endangered).

See Appendix S1 for details on conifer species occurring in each island, its degree of endemism and conservation status. 

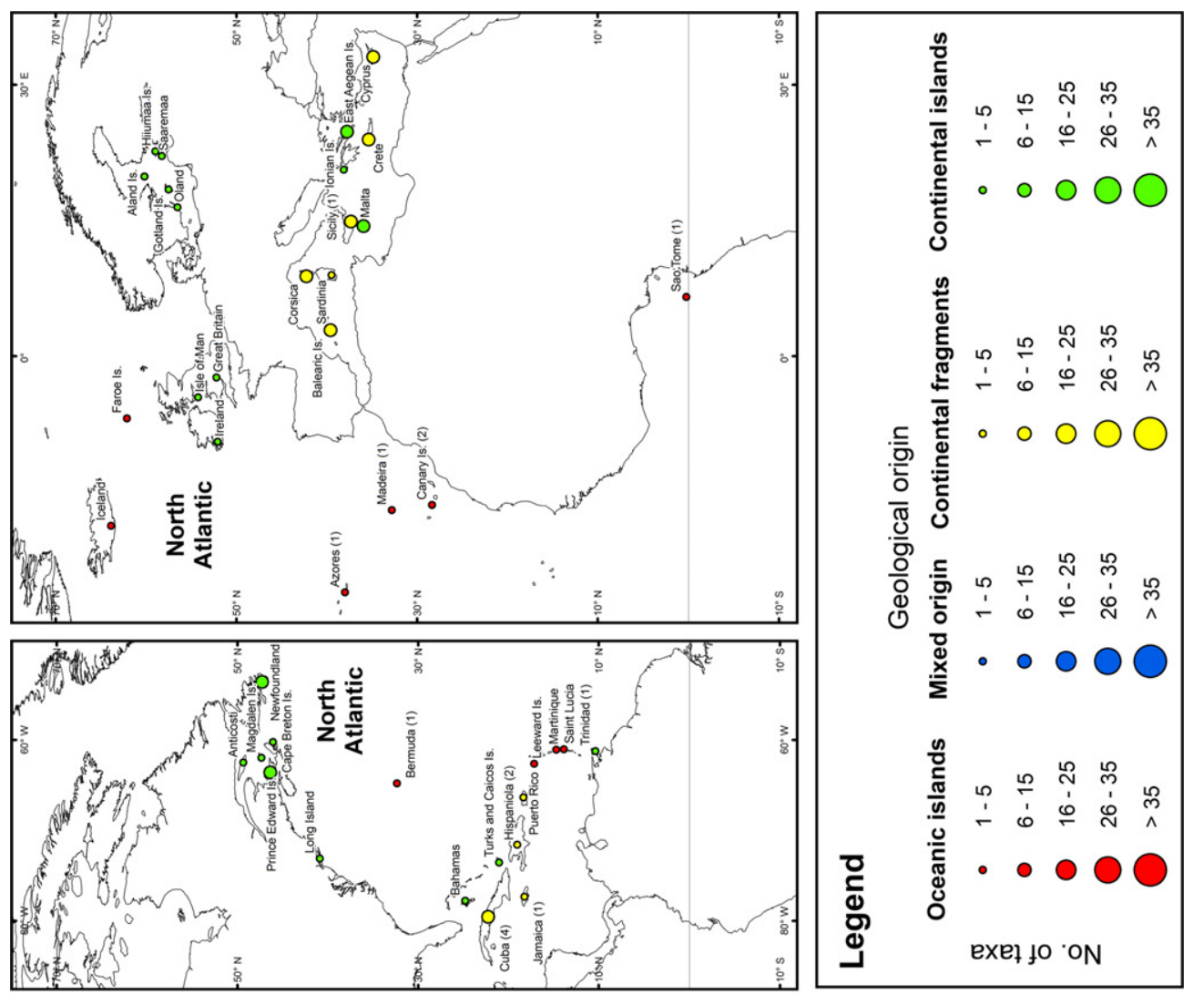

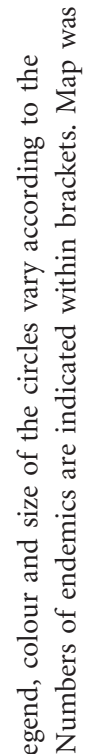

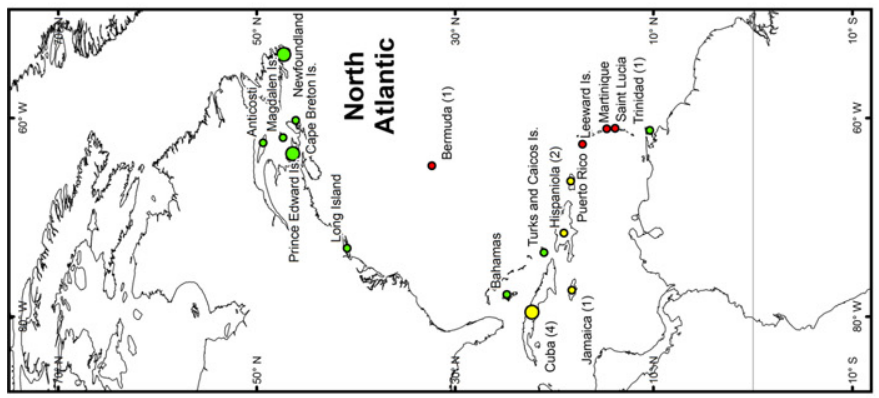

(a)
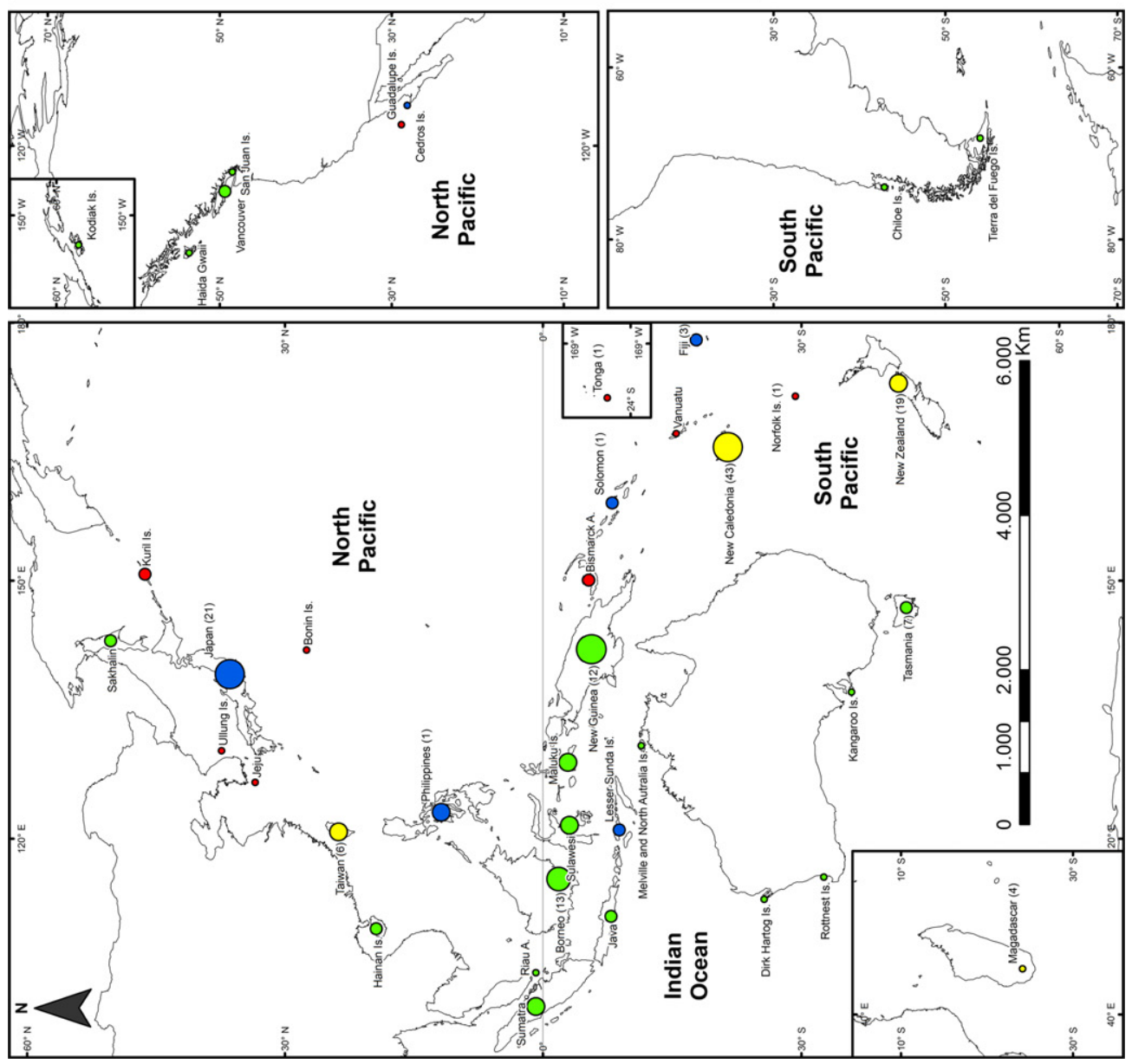

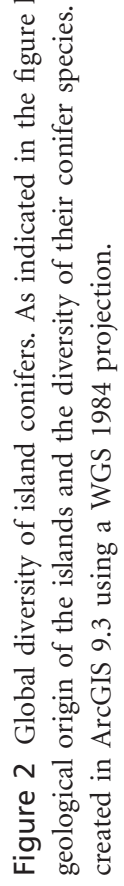




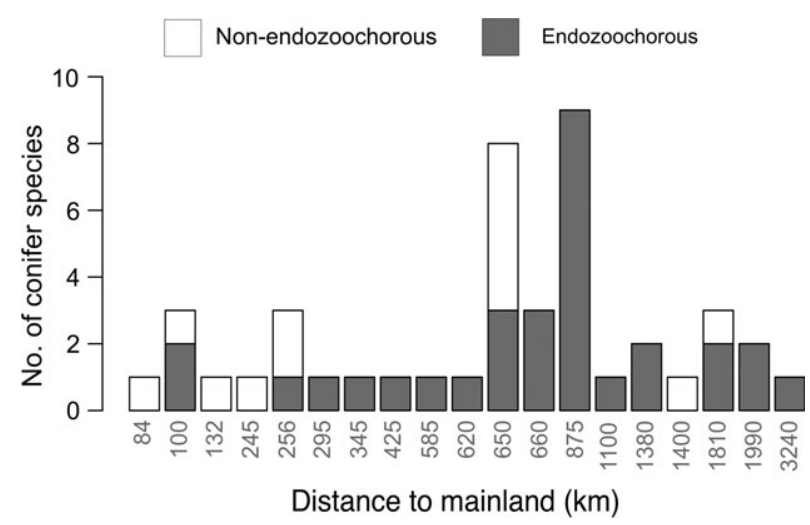

Figure 3 Stacked bar plot showing absolute numbers of endozoochorous and non-endozoochorous conifer species from islands of oceanic and mixed origin ( $y$-axis), as distance from the closest continental land mass increases ( $x$-axis). Spearman's correlation showed a significant positive trend $\left(r_{\mathrm{s}}=0.42\right.$, $P<0.05$ ), that is, the more remote the island is, the more endozoochorous species it harbours. Islands corresponding to each of the distances in the $x$-axis ranged as follows: Jeju $(84 \mathrm{~km})$, Canary Islands (100 km), Ullung Island (132 km), São Tomé $(245 \mathrm{~km})$, Guadalupe Island $(256 \mathrm{~km})$, Iceland $(295 \mathrm{~km})$, Saint Lucia $(345 \mathrm{~km})$, Martinique $(425 \mathrm{~km})$, Leewards $(585 \mathrm{~km})$, Faroes $(620 \mathrm{~km})$, Kuril Islands $(650 \mathrm{~km})$, Madeira $(660 \mathrm{~km})$, Bismarck archipelago $(875 \mathrm{~km})$, Bermuda $(1100 \mathrm{~km})$, Azores $(1390 \mathrm{~km})$, Norfolk Island $(1400 \mathrm{~km})$, Vanuatu $(1810 \mathrm{~km})$, Bonin Islands $(1990 \mathrm{~km})$, Tonga archipelago $(3240 \mathrm{~km})$. See Table 2 and Appendix S1 for numbers and names of the species in each of the islands.

increased their category of threat. In contrast, 26 conifers previously threatened have decreased their degree of threat; of these 26 species, seven continue to be threatened and 19 are currently out of threat.

Whether we consider the total threatened conifers or only those that are highly endangered, over half of the species (52\% and 54\%, respectively) occur on islands (Table 2). Island conifers have also increased their degree of threat relative to the previous assessment (IUCN, version 2011.2). Thus, 16 species have been added to the threatened categories and 8 have increased their previous category of threat. Only nine species previously threatened have decreased their threat degree (two species continue being threatened and seven are currently out of threat). Leaving aside the family Sciadopityaceae, which comprises only one near threatened species distributed in Japan, we found significant differences between conifer families regarding the degree of threat to their insular taxa ( $G$-test: $G_{4}=18.29, P<0.01$, after Bonferroni correction). The family Araucariaceae is the most threatened on islands, due to $66 \%$ of their insular species being vulnerable, endangered or critically endangered. This value was significantly higher than those of Cupressaceae (29\%), Pinaceae (22\%) and Podocarpaceae (27\%) (G-test: $P<0.01$ for all comparisons after Bonferroni correction). Four of the 11 insular species of Taxaceae are threatened (36\%); however, there were no significant differences with respect to the threatened species within Araucariaceae ( $G$-test: $G_{1}=2.77$, $P=0.096$ ). Focusing on the highly endangered species (CR, EN), no significant differences were observed between conifer families either ( $G$-test: $P>0.01$, after Bonferroni correction) and they ranked as follows: Araucariaceae (34\%), Cupressaceae $(19 \%)$, Podocarpaceae (18\%), Taxaceae (18\%) and Pinaceae $(12 \%)$. Notably, a high percentage $(72 \%)$ of these insular threatened conifers are endemics. No significant differences were found with regard to the proportion of insular threatened conifers according to the geological origin of the island nor among the five oceanic regions considered ( $G$-test $>0.05$ for all comparisons).

\section{DISCUSSION}

\section{Diversity and distribution of insular conifers}

The large representation of coniferous species on islands is evident because the natural range of $52 \%$ of all species includes an insular distribution. A total of $40 \%$ of all these insular species belong to the family Podocarpaceae, which shows an outstanding representation in the Pacific Ocean (86\% of all insular species from Podocarpaceae occur in this oceanic region).

Overall, 37 conifer species are found on islands of oceanic origin, $22 \%$ of them being endemics. This provides evidence in many cases of their ability to successfully overcome the marine barrier separating continents from isolated volcanic territories and evolve further there. Nevertheless, this ulterior evolution is not essential to attain endemic status if the conifer is a palaeoendemism. Indeed, we do know that at least one of these 37 conifer species, the Canary Islands pine (Pinus canariensis), endemic to this archipelago and already present at least 13 My BP (García-Talavera et al., 1995), was widely distributed in the past in the Mediterranean Basin. It became extinct in that region after the onset of the Pleistocene Glaciation events (Millar, 1993; Morla et al., 2003).

Our results show that islands of continental origin harbour a significantly higher number of conifer species than islands of oceanic and mixed origin. Continental islands, due to their isolation after being part of a larger land mass, are typically closer to the continents than oceanic islands. They contained a portion of continental biota at the time of their formation, although its richness usually declines as an adjustment to a smaller and isolated environment (Thornton, 2007; Whittaker \& Fernández-Palacios, 2007). They would thus be expected to harbour more conifer species than islands of oceanic or mixed origin. Nevertheless, the diversity of endemic species distributed over continental and mixed or oceanic islands was not significantly different. The intrinsic characteristics of volcanic islands as isolated entities with reduced gene-flow, combined with other factors such as habitat diversity or a geologically dynamic history, lead to generally high levels of endemism despite their low species diversity (Emerson, 2002). These speciation processes seem 
to underlie the lack of significant differences in the number of endemic conifers from continental vs. oceanic or mixed islands.

Large islands harbour a greater number of conifer species and endemics than smaller islands (Fig. 1). However, the diversity of New Caledonia is quite striking in this context. This island of $c \cdot 18,600 \mathrm{~km}^{2}$ is the most diverse of all islands without being the largest. It harbours 44 conifer species and 43 of them are unique to the island, including several radiation events in genera such as Agathis (with five endemic species), Dacrydium (four species), Podocarpus (seven species) and especially Araucaria (13 of the 19 world species) (see Appendix S1). Factors such as the long and extreme isolation of New Caledonia and its geological peculiarities have played a role in this speciation process, which may have been produced by vicariance or from ancestors that successfully colonized the island after dispersal (Farjon, 2008).

The number of islands varies considerably among the oceans. The Pacific Region has the largest ocean on Earth and has the highest abundance of islands (Koppers, 2009). Accordingly, and also due to the proximity of the richest continent in conifers (Asia), Pacific islands show the highest diversity of conifers and the largest proportion of endemics. Besides the island abundance in the different oceanic regions, the richness of continental species capable of colonizing oceanic islands also appears to be a determinant factor in the geographical pattern of insular conifers. In the South Atlantic, where only two conifer species occur on a continental island, the number of islands is very small and they are mostly of volcanic origin (Klügel, 2009). Therefore, remoteness is a predominant characteristic in this region. Besides, Africa, Europe and South America are the poorest continents in conifer richness, harbouring about $4-5 \%$ of the conifer species (Eckenwalder, 2009). The combination of these two factors, namely the remoteness of the islands and the relatively poor conifer diversity of the nearest continental land masses, must be the underlying cause of this striking absence of conifers in the South Atlantic islands of volcanic and mixed origin.

\section{Ability for long-distance dispersal}

Dispersal syndromes largely determine the ability to colonize remote environments such as volcanic islands (Ridley, 1930; Carlquist, 1974; Chambers \& MacMahon, 1994; Gillespie et al., 2012). Among those syndromes favourable for longdistance dispersal, conifers display anemochory and endozoochory, lacking hydrochory and epizoochory (sensu van der Pijl, 1982). The predominance of endozoochory among the conifer species occurring on islands of oceanic origin highlights the suitability of this syndrome to overcome the sea barrier that characterizes isolated islands never connected to the mainland. This result agrees with the evidence for the angiosperms, in which a greater efficiency of endozoochory over anemochory in successfully colonizing remote islands has been described (Carlquist, 1967). Phylogeographical studies have also demonstrated that endozoochory seems to be predominant in multiple colonization events to oceanic islands (Vargas, 2007). In addition, this syndrome is directly involved in mechanisms of secondary seed dispersal, which might be a common long-distance dispersal mechanism world-wide (Moore, 1999; Nogales et al., 2012).

Outstanding long-distance dispersal events featured by conifers include the colonization of Tonga $(800 \mathrm{~km}$ away from Fiji) by Podocarpus pallidus, Bonin (910 km off Honshu) by Juniperus chinensis and Juniperus taxifolia, Azores (950 km away from Madeira) by Juniperus brevifolia and Taxus baccata, Bermuda (1110 km off South Carolina) by Juniperus bermudiana or Fiji (1170 km off New Caledonia) by Acmopyle sahniana, Agathis macrophylla, Dacrycarpus imbricatus, Dacrydium nausoriense, Dacrydium nidulum, Podocarpus affinis, Podocarpus neriifolius and Retrophyllum vitiense. Nonetheless, conifers have failed to colonize other volcanic archipelagos that have been successfully colonized by angiosperms, such as Galápagos, Marquesas, Society, Hawaii, Juan Fernández, Tristan da Cunha or Mascarenes, very likely due to their extreme isolation, scarce continental species pool or both. Overall, our data support the general idea of plants displaying endozoochory having greater chances of success in colonizing insular territories.

\section{Degree of threat}

Islands display a great diversity of conifers and have undoubtedly been a key factor in the evolution and speciation of many current species. However, besides the endemism and unique characteristics resulting from evolutionary isolation, the limited range and small population sizes of island organisms make them highly sensitive to anthropogenic disturbance (Frankham, 1998). Humans, in fact, have heavily affected island ecosystems, resulting in a significant number of extinctions and leading many taxa to a threatened status (Whittaker \& Fernández-Palacios, 2007; Kingsford et al., 2009). According to our search, 52\% and 54\% of all threatened and critically endangered conifers, respectively, show an insular distribution. These figures, together with the fact that $72 \%$ of the insular threatened conifers are endemics, highlight the vulnerability of insular conifers and, especially, of the unique taxa with a limited island distribution. Among conifer families, Araucariaceae is the most threatened in insular territories. Around $66 \%$ of their island taxa are threatened, most of them being endemics of New Caledonia. In this Pacific island, which certainly is a hotspot of conifer diversity, more than a half of the conifer species are threatened, which deserves special attention from the conservation point of view. The lack of significant differences with regard to the proportion of insular threatened conifers among the five oceanic regions considered reflects the globalization of threats in island systems. Thus, the threatened status of the insular conifers seems to be independent of their ocean region, and also of the geological origin of the island. 
Worryingly, the last update in the conservation status of the conifers reveals an overall increase in the threat degree. Major threats to conifer species survival are linked to human activities and among others involve (1) direct exploitation through logging, (2) anthropogenic fires combined with overgrazing, (3) conversion of forested ecosystems to pasture, (4) exploitation of non-timber resources such as resin, edible seeds or medicines or (5) genetic depletion through selective removal of individuals (see Farjon \& Page, 1999 for details). These threats are still prevalent in most of the islands across the planet, and many of them are aggravated by the peculiarities of insular ecosystems. For instance, herbivory by introduced mammals on oceanic islands has been shown to have a dramatic effect on population dynamics of native plant communities (Coblentz, 1978; Courchamp et al., 2003). Unless conservation measures are taken, the combination of these threats will probably compromise the persistence of many conifer species and populations on islands world-wide.

\section{CONCLUSIONS}

This review offers a more comprehensive understanding of insular conifers, which represent about half of all living species in this group of plants. We have focused on the general patterns of their diversity and distribution, dispersal potential and conservation status. Besides highlighting the outstanding representation of conifers on island territories and across the different ocean regions, our study is evidence of the key role that oceanic islands, never connected to the mainland, have on evolutionary mechanisms of speciation in this group of plants. Whilst the Pacific may be considered as a hotspot for diversification, the South Atlantic Ocean islands are almost devoid of conifers. This contrast seems to be the result of a combination of factors in this latter region, such as a low number of islands, volcanic origin and thus remoteness of many of them, and the paucity of conifer diversity in the source mainland areas.

The wide distribution of conifers reflects their great potential for dispersal and colonization. Endozoochory has emerged as the most frequent syndrome in those conifer species established on islands, illustrating its importance for long-distance dispersal events.

More than half of the threatened conifer species show an insular distribution, and many of them are island endemics. Isolation itself does not necessarily influence the risk of extinction (Caujapé-Castells et al., 2010). However, direct or indirect human impact on islands has caused the extinction of many taxa and is currently threatening others, conifers being no exception from this trend. Besides the major threats specified for conifers, habitat loss or degradation, invasive species, climate change and pollution, overexploitation, disease and loss of mutualisms are the main threat factors for insular organisms in general (Whittaker \& Fernández-Palacios, 2007; Kingsford et al., 2009; Caujapé-Castells et al., 2010). As awareness of these threats increases, effective policies become urgently necessary to prevent and mitigate their effects, aimed at the conservation not only of conifers, but other unique organisms that currently evolve in island ecosystems.

\section{ACKNOWLEDGEMENTS}

This work has been supported by the Ministerio de Educación y Ciencia (CGL 2010-18759) and the Organismo Autónomo de Parques Nacionales (project 051/2010). We would like to thank J.P., J.M.O. and A.H., who kindly reviewed an earlier version of the manuscript, offering valuable comments. Eugene Schupp and an anonymous referee made useful comments and suggestions to improve the manuscript.

\section{REFERENCES}

Carlquist, S. (1967) The biota of long-distance dispersal. V. Plant Dispersal to Pacific Islands. Bulletin of the Torrey Botanical Club, 94, 129-162.

Carlquist, S. (1974) Island biology. Columbia University Press, New York, NY.

Caujapé-Castells, J., Tye, A., Crawford, D.J., Santos-Guerra, A., Sakai, A., Beaver, K., Lobin, W., Vincent Florens, F.B., Moura, M., Jardim, R., Gómes, I. \& Kueffer, C. (2010) Conservation of oceanic island floras: present and future global challenges. Perspectives in Plant Ecology, Evolution and Systematics, 12, 107-129.

Chambers, J.C. \& MacMahon, J.A. (1994) A day in the life of a seed: movements and fates of seeds and their Implications for natural and managed systems. Annual Review of Ecology and Systematics, 25, 263-292.

Chaw, S.-M., Parkinson, C.L., Cheng, Y., Vincent, T.M. \& Palmer, J.D. (2000) Seed plant phylogeny inferred from all three plant genomes: monophyly of extant gymnosperms and origin of Gnetales from conifers. Proceedings of the National Academy of Sciences USA, 97, 4086-4091.

Coblentz, B.E. (1978) The effects of feral goats (Capra hircus) on island ecosystems. Biological Conservation, 13, 279-286.

Courchamp, F., Chapuis, J.-L. \& Pascal, M. (2003) Mammal invaders on islands: impact, control and control impact. Biological Reviews, 78, 347-383.

Eckenwalder, J.E. (2009) Conifers of the World: the complete reference. Timber Press, Portland, OR.

Emerson, B.C. (2002) Evolution on oceanic islands: molecular phylogenetic approaches to understanding pattern and process. Molecular Ecology, 11, 951-966.

Farjon, A. (2008) A natural history of conifers. Timber Press, Portland, OR.

Farjon, A. (2010) A handbook of the World's conifers. Brill Academic Publishers, Leiden.

Farjon, A. \& Page, C.N. (1999) Conifers. Status survey and conservation action plan. IUCN/SSC Conifer Specialist Group, IUCN, Gland and Cambridge.

Francis, J.E. \& Poole, I. (2002) Cretaceous and early Tertiary climates of Antarctica: evidence from fossil wood. Palaeogeography, Palaeoclimatology, Palaeoecology, 182, 47-64. 
Frankham, R. (1998) Inbreeding and extinction: island populations. Conservation Biology, 12, 665-675.

García-Talavera, F., Sánchez-Pinto, L. \& Socorro, S. (1995) Vegetales fósiles en el complejo traquítico-sienítico de Gran Canaria. Revista de la Academia Canaria de Ciencias, 7, 77-91.

Gaston, K.J. (2009) Extinction. Encyclopedia of Islands (ed. by R.G. Gillespie and D.A. Clague), pp. 281-286. University of California Press, Berkeley, CA.

Gillespie, R.G., Baldwin, B.G., Waters, J.M., Fraser, C.I., Nikula, R. \& Roderick, G.K. (2012) Long-distance dispersal: a framework for hypothesis testing. Trends in Ecology \& Evolution, 27, 47-56.

He, T., Pausas, J.G., Belcher, C.M., Schwilk, D.W. \& Lamont, B.B. (2012) Fire-adapted traits of Pinus arose in the fiery Cretaceous. New Phytologist, 194, 751-759.

IUCN (2011) IUCN Red List of Threatened Species. Version 2011.2. Available at: http://www.iucnredlist.org/ (accessed 11 May 2012).

IUCN (2013) IUCN Red List of Threatened Species. Version 2013.1. Available at: http://www.iucnredlist.org/ (accessed 16 September 2013).

Johnson, M., Vander Wall, S. \& Borchert, M. (2003) A comparative analysis of seed and cone characteristics and seeddispersal strategies of three pines in the subsection Sabinianae. Plant Ecology, 168, 69-84.

Kingsford, R.T., Watson, J.E.M., Lundquist, C.J., Venter, O., Hughes, L., Johnston, E.L., Atherton, J., Gawel, M., Keith, D.A., Mackey, B.G., Morley, C., Possingham, H.P., Raynor, B., Recher, H.F. \& Wilson, K.A. (2009) Major conservation policy issues for biodiversity in Oceania. Conservation Biology, 23, 834-840.

Klügel, A. (2009) Atlantic region. Encyclopedia of Islands (ed. by R.G. Gillespie and D.A. Clague), pp. 63-67. University of California Press, Berkeley, CA.

Koppers, A.A.P (2009) Pacific region. Encyclopedia of Islands (ed. by R.G. Gillespie and D.A. Clague), pp. 702-715. University of California Press, Berkeley, CA.

Leslie, A.B., Beaulieu, J.M., Crane, P.R. \& Donoghue, M.J. (2013) Explaining the distribution of breeding and dispersal syndromes in conifers. Proceedings of the Royal Society B: Biological Sciences, 280. doi:10.1098/rspb.2013.1812 [Epub ahead of print].

Losos, J.B. \& Ricklefs, R.E. (2009) Adaptation and diversification on islands. Nature, 457, 830-836.

MacArthur, R.H. \& Wilson, E.O. (1967) The theory of Island biogeography. Princeton University Press, Princeton, NJ.

Millar, C.I. (1993) Impact of the Eocene on the evolution of Pinus L. Annals of the Missouri Botanical Garden, 80, 471-498.

Moore, P.D. (1999) Ecology: a shrike for mobility. Nature, 397, 21-23.

Morla, C., Alcalde, C., Postigo, J. \& Barrón, E. (2003) Paleobiogeografía de Pinus canariensis: estróbilos y semillas fósiles del Plioceno ibérico (cuenca del Bajo Segura, Alicante, España). La Biogeografía: ciencia geográfica y ciencia básica. (ed. by M.A. Arozena, E. Beltrán and P. Dorta), pp. 313-323.
Actas del II Congreso español de Biogeografía, Ser. Publ. Univ. La Laguna. La Laguna.

Nogales, M., Heleno, R., Traveset, A. \& Vargas, P. (2012) Evidence for overlooked mechanisms of long-distance seed dispersal to and between oceanic islands. New Phytologist, 194, 313-317.

van der Pijl, L. (1982) Principles of dispersal in higher plants. Springer-Verlag, Berlin.

Pimm, S.L., Jones, H.L. \& Diamond, J. (1988) On the risk of extinction. The American Naturalist, 132, 757-785.

R Core Team (2013) R: a language and environment for statistical computing. R Foundation for Statistical Computing, Vienna, Austria.

Renner, S. (2004) Plant dispersal across the Tropical Atlantic by wind and sea currents. International Journal of Plant Sciences, 165, S23-S33.

Ridley, H.N. (1930) The dispersal of plants throughout the World. L. Reeve \& Co., Ashford.

Thornton, I. (2007). Island colonization. The origin and development of Island communities. Cambridge University Press, La Trobe University, Melbourne, Vic.

Vander Wall, S.B. (2003) Effects of seed size of wind-dispersed pines (Pinus) on secondary seed dispersal and the caching behavior of rodents. Oikos, 100, 25-34.

Vander Wall, S.B. \& Balda, R.P. (1981) Ecology and evolution of food-storage behavior in conifer-seed-caching corvids. Zeitschrift für Tierpsychologie, 56, 217-242.

Vargas, P. (2007) Are Macaronesian islands refugia of relict plant lineages? a molecular survey. Phylogeography of southern European refugia: evolutionary perspectives on the origins and conservation of European biodiversity (ed. by S. Weiss and N. Ferrand), pp. 297-314. Springer Netherlands, Berlin.

Whittaker, R.J. \& Fernández-Palacios, J.M. (2007) Island biogeography: ecology, evolution, and conservation, 2nd edn. Oxford University Press, New York, NY.

\section{SUPPORTING INFORMATION}

Additional Supporting Information may be found in the online version of this article:

Appendix S1 Database of islands or archipelagos that harbour conifer species, showing their geographical region, area $\left(\mathrm{km}^{2}\right)$, geological origin, distance from mainland $(\mathrm{km})$ in the case of volcanic and mixed-origin islands, and native conifer diversity (list of the species, conservation status, and number of taxa and endemics).

\section{BIOSKETCH}

Authors of this article are members or collaborators of the Island Ecology and Evolution Research Group (GEEI, IPNACSIC) https://www.ipna.csic.es/dept/agro/eei/en and the Island Ecology and Biogeography Research Group (personal webpage of J.M.F.-P. http://jmferpal.webs.ull.es/Welcome.html). Inter- 
ests of both research groups are focused on ecology, evolution, biogeography and conservation biology of insular organisms.

Author Contributions: M.N. and B.R. conceived the ideas; B.R., V.A. and J.M.F.-P. collected the data; B.R., M.N. and
V.A. analysed the data; and B.R., M.N., V.A. and J.M.F.-P. led the writing.

Editor: Marcel Rejmanek 